Information for citation:

Mingaleva Zh. A., Mirskikh I. Yu. K voprosu o pravovom regulirovanii informatsii v usloviyakh informatsionnoy ekonomiki [Legal Regulation of Information in the Conditions of Information Economy]. Vestnik Permskogo Universiteta. Juridicheskie Nauki - Perm University Herald. Juridical Sciences. 2017. Issue 38. Pp. $430-445$. (In Russ.). DOI: 10.17072/1995-4190-2017-38-430-445.

UDC 347.78

DOI: $10.17072 / 1995-4190-2017-38-430-445$

\title{
LEGAL REGULATION OF INFORMATION IN THE CONDITIONS OF INFORMATION ECONOMY
}

\section{Yu. Mirskikh}

Perm State University

15, Bukireva st., Perm, 614990, Russia

ORCID: 0000-0001-7278-8843

ResearcherID: E-8002-2016

Articles in DB "Scopus" / "Web of Science":

DOI: $10.1016 /$ j.sbspro.2013.06.197 DOI: 10.5829 /idosi.wasj.2013.27.elelc.42

DOI: $10.1016 /$ j.sbspro.2013.06.437 DOI: 10.5829 /idosi.mejsr.2013.13.pl.14017

DOI: $10.1016 /$ j.sbspro.2012.06.886 DOI: $10.17072 / 1995-4190-2015-3-62-70$

DOI: 10.5539 /ass.v10n24p257 DOI: $10.17072 / 1995-4190-2016-33-311-318$

e-mail: gloriaday@mail.ru

\section{Zh. A. Mingaleva}

Perm National Research Polytechnic University 29, Komsomolskiy prospekt, Perm, 614000, Russia

ORCID: 0000-0001-7674-7846

ResearcherID: E-8001-2016

Articles in DB "Scopus" / "Web of Science"

DOI: $10.1016 /$ j.sbspro.2013.06.197

DOI: $10.1016 / \mathrm{j}$.sbspro. 2013.06 .437

DOI: $10.1016 /$ j.sbspro, 2012.06 .886

DOI: $10.5539 /$ ass.v10n $24 \mathrm{p} 257$

DOI: 10.5829 /adosi.wasj.2013.27.elelc.42

DOI: 10.5829 /idosi mejsr.2013.13.pl.14017

DOI: $10.2298 / \mathrm{TSCI} 150330087 \mathrm{M}$

DOI: $10.1016 /$ j.sbspro.2013.06.482

DOI: $10.1016 /$ j.sbspro.2013.07.024

DOI: $10.17072 / 1995-4190-2015-3-62-70$

DOI: $10.17072 / 1995-4190-2016-33-311-318$

e-mail: mingal1@psu.ru

Introduction: in the conditions of information economy, the issues of legal regulation of information exchange, creation, storage, multiplication, reproduction and use of information are of great current significance. Nevertheless, there are still a lot of legal collisions and unsolved questions. The necessity to change the order of the state regulation of legal relations concerning creation, storage, dissemination and use of information proves the importance and current relevance of studying this sphere. Purpose: to analyze the essence, nature and main features of legal regulation of information and information objects, to reveal the main problems and suggest possible solutions. Methods: the methodological framework of the research is based on a set of scientific methods with a leading role of analysis and synthesis, methods of interdisciplinary and comparative law approach. Results: it has been established that the insufficient state of Russian legislation has led to ambiguous understanding of the essence of information, its role among other objects of property rights, its correlation with documented information. The question of the possibility to apply the institutions of property rights and intellectual prop- 
erty rights to information resources still remains the most difficult. Conclusions: in order to overcome collisions and contradictions in the information sphere, it is important to apply differential regulation of information as a special object of intellectual property rights. This also refers to creation, storage, reproduction and any other kind of use of information. To improve the legal regulation of information, it is suggested to use a new term "information object".

Keywords: intellectual property; information; information objects; information economy

\section{Information in Russian}

\section{К ВОПРОСУ О ПРАВОВОМ РЕГУЛИРОВАНИИ ИНФОРМАЦИИ В УСЛОВИЯХ ИНФОРМАЦИОННОЙ ЭКОНОМИКИ}

\section{И. Ю. Мирских}

Кандидат юридических наук, доцент кафедры гражданского права Пермский государственный национальный исследовательский университет 614990, Россия, г. Пермь, ул. Букирева, 15

ORCID: 0000-0001-7278-8843

ResearcherID: E-8002-2016

Статьи в БД «Scopus» / «Web of Science»:

DOI: $10.1016 /$ j.sbspro.2013.06.197 DOI: 10.5829/idosi.wasj.2013.27.elelc.42

DOI: $10.1016 /$ j.sbspro.2013.06.437 DOI: $10.5829 /$ idosi.mejsr.2013.13.pl/44017

DOI: $10.1016 /$ j.sbspro.2012.06.886 DOI: $10.17072 / 1995-4190-2015-3-62-70$

DOI: $10.5539 /$ ass.v10n24p257 DOI: $10.17072 / 1995-4190-2016-33-311-318$

e-mail: gloriaday@mail.ru

\section{Ж. А. Мингалева}

Доктор экономических наук, профеєсор кафелры экономики и управления промышленным производством Пермский национальный исслеґовательский политехнический университет 614990, Россия, г. Пермь, Комсомольский проспект, 29

ORCID: 0000-0001-7674-7846

ResearcherID: E-8001-2016

Статьи в БД «Scopus» «Web of Science»:

DOI: $10.1016 /$ j.sbspro.2013.06.197

DOI: $10.1016 /$ isbspro.2013.06.437

DOI: $10.1016 /$ j.sbspro.2012.06.886

DOI: $10.5539 /$ ass.v10n24p 257

DOI: 10.5829 /idosi.wasj 2013.27 elelc.42

DOI: $10.2298 / \mathrm{TSCI} 150330087 \mathrm{M}$

DOI: $10.1016 /$ j.sbspro.2013.06.482

DOI: $10.1016 /$ j.sbspro.2013.07.024

DOI: $10.17072 / 1995-4190-2015-3-62-70$

DOI: $10.17072 / 1995-4190-2016-33-311-318$

DO1: 10.5829/idosi.mejsr.2013. 13.pl. 14017

e-mail:mingall @ psurnt

Введение: вопросы гражданско-правового регулирования гражданского оборота инфорлапии, отношений по ее созданию, хранению, тиражированию, воспроизведению и использованию обладают особой актуальностью в условиях информационной экономики. Однако, несмотря на попытки законодателя урегулировать сферу информационных отношений единообразным образом, в законодательстве до сих пор остается множество нерешенных вопросов и коллизий. Необходимость изменения порядка регулирования отношений, возникающих по поводу создания, хранения, распространения и использования информации, применения информационных технологий, требует более глубокого и всестороннего изучения данной темы, сопоставления смежных институтов и анализа сферы их деятельности. Цель: авторы анализируют сущуность и основные особенности правового регулирования информации, информационных объектов, выявляют проблемные вопросы и предлагают возможные пути их решения. Методы: использована совокупность методов научного познания, методы анализа и синтеза, методы междисии- 
плинарного подхода и сравнительного правоведения. Результаты: определено, что в российском праве вследствие неопределенности законодательства среди ученыхисследователей информационных отношений в обществе складывается неоднозначное понимание относительно сущности информации, ее места среди других объектов имущественных прав, а также соотношения ее с документированной информацией как зафиксированной на материальном носителе. Наиболее сложным остается вопрос о применении к информационным ресурсам и их составляющим института права собственности и института интеллектуальных прав. Выводы: для устранения коллизий и противоречий в этой области необходимо введение дифференцированного регулирования относительно такого объекта интеллектуальной собственности, как информаиия, а также действий, направленных на ее создание, хранение, воспроизведение, тиражирование, распространение, иных действий по ее использованию и иных операпии с пей. Представляется возможным для использования в законодательстве РФ дать определение понятия информаџионного объекта.

Ключевые слова: интеллектуальная собственность; информация; информационные объекты; информационная экопомика

\section{Introduction}

Information technologies form the basis for functioning of the modern society. The information sphere has a great influence on all aspects of human life. Nowadays information has become a very important communication and political resource. It catalyzes economic and market relations. In this context, the increasing legal value of information and information technologies is beyond doubt.

The first attempts to establish an official legal status of information were made in the $1940 \mathrm{~s}$. The idea of the principle of free international information exchange appeared in 1945 at the UNO conference, held in Mexico City. The following year in 1946, the General Assembly of the UN adopted the resolution No. 59(1) which declared that principle. Legalization of the right to information in the Universal Declaration of Human Rights in 1948 became the next step. In Russia the key right to free search, reception, transfer, generation and dissemination of information is enshrined in the Constitution (Article 29).

The necessity to provide rightful and effective participation of Russia in various international organizations within the framework of the WTO and TRIPS involves the effective use of the existing information potential.

The necessity to develop cooperation of Russia with foreign countries in the sphere of intellectual property and information made the legislature bring civil legislation in compliance with the principles of international law [21].
The development of communication facilities, communication technologies and computer engineering, use of modern and high-speed equipment for information processing and transfer caused the need for quantitative measurement of the information volumes. Transactions for purchase of different software and audiovisual production are widespread.

Extension of the sphere of information trade and exchange has led to growth of the volume of information, and information resources trade has become an important item of export and import in many countries. According to the WTO data, in 2014 the intellectual property circulation in the USA made up 131,636 million dollars ${ }^{1}$. The USA takes the first place in the sphere of intellectual property export. Unfortunately, Russia is not among the leaders in this sphere. This can be explained by the insufficient state of national legislation in the sphere of intellectual property rights protection.

\section{Main Part}

Nowadays scientists and official documents suggest a lot of definitions of the term "information".

At the same time, a lot of complex research works devoted to a wide range of questions concerning the essence and status of information take

\footnotetext{
${ }^{1}$ International Trade Statistics 2015. Available at: https:// www.hse.ru/data/2015/11/02/1078233778/its2015_e.pdf (accessed 28.10.2016).
} 
place [3, p. 17]. There are many scientific research works on legal problems of some particular kinds and groups of information objects [20, p. 330]

Among the most clear, logical, and wellstructured definitions of information one can mention the definition by S. I. Ozhegov: "information is:

1) data about the surrounding world and processes existing in it, which can be received and perceived by a human or special equipment;

2) data about the condition of something" [11, p. 25].

Another complex definition of information was given by K. Shennon, who defined information as a special "aspect of social communication that is a report being passed from one subject to another which can be translated not only by means of language but also with the use of technology" [14, p. 245]. Thus, from the middle of the $20^{\text {th }}$ century information becomes a scientific category which embraces communication between people, between a man and machine, between machines, translation of data from one system into another. In such a context, information has become one of the main cybernetic categories.

Nowadays it is possible to name the following conceptions of information in legal literature.

1) Technocentric conception. It regards any information as data $[18, \mathrm{p} 47]$.

2) Anthropocentrie conception. It is based on the thesis that information is data about the surrounding world. Some researchers consider that this approach do not take into account genetic information and abstract information [19, p. 224].

3) Vital conception. It considers information to be "a number of encoded data reports which are necessary for making decisions and their implementation" [23, p. 45].

4) Integration conception. It regards information as "the understanding, interpretation of reports and data by a human which is connected with the previous knowledge and definitions" [13, p. 18].
5) Non-deterministic approach. It suggests not defining the term "information" because of the impossibility and lack of necessity to define the basic and original categories like energy and substance $[17$, p. 56].

The process of legal regulation of information is objectively very complex since information itself is one of the most complex social phenomena.

The problems of legal regulation of the civil circulation of information, relations for its creation, storage, copying, reproduction and use are of particular relevance in the conditions of information economy.

The definition of information is formulated in Federal Law of 27.07.2006 No. 149-FZ "On Information, Information Technologies and Protection of Information" . According to Article 2 of this law, "information is data, reports, etc. independent of the form of their presentation". Such wide understanding of information causes several problems. Intellectual property expressed in electronic form (information products) is regulated by Article 29 of the Constitution of Russia, introducing free access to information and its free use. On the other hand, it is regulated by Article 44 of the Constitution, which introduces a special procedure of circulation of intellectual property. The content of right to information and the content of exclusive rights concerning information products do not coincide (Article 29 of the Constitution and Article 1229 of the Civil Code of Russia). Evidently, the right to information is limited by intellectual property rights of the authors and right holders. That is why the state has to secure fundamental rights and liberties and also to formulate guarantees and mechanisms which make it possible to exercise these rights.

Federal Law "On Information, Information Technologies and Protection of Information" of

\footnotetext{
${ }^{1}$ On information, information technologies and information protection: Federal Law No. 149-FZ (27.07.2006). Rossiyskaya gazeta-Russian Gazette. 2006. No. 165.
} 
27.07.2006 No. 149-FZ1 (Law on information) and Part Four of the Civil Code ${ }^{2}$ made the appropriate amendments to Federal Law No. 98-FZ "On Commercial Secrets" ${ }^{3}$ of 29.07.2004.

After excluding information from the objects of civil rights (Article 128 of the Civil Code), the question about the legal nature of information has become more complicated. According to the legislator's approach, an information object (in a broad sense) cannot be regarded as a commodity or a kind of property. This contradicts the provisions of Federal Law No. 149-FZ, stating that 1) information is an object of civil relations (Article 5); 2) information can be transferred according to the terms of a contract to other persons (Article 6). Such regulations do not coincide with the actions of the legislature, who excluded information from the objects of civil legal relations in the Civil Code of Russia). Some researchers come to the conclusion that any information can become an object of civil relations, though the legislature has another point of view.

The term "information object" is closely connected with the category "information" because it refers to the objects which are created and can function only in the sector of information or by means of information technologies. The category of information, of course, is much wider in comparison with the category "results of intellectual activity".

An information product as an object of property rights can be and should be regarded in a narrow sense of the term. In this context, only concrete intellectual property objects can be referred to information objects (information products). This can be proved by the following:

1) It is important to delimit different kinds of objects existing in electronic form and referring to the objects of civil rights. For example, e-money,

\footnotetext{
${ }^{1}$ On information, information technologies and information protection: Federal Law No. 149-FZ (27.07.2006). Rossiyskaya gazeta .- Russian Gazette. 2006. No. 165.

${ }^{2}$ The Civil code of the Russian Federation (part four): the Federal Law from 18.12.2006 No. 230-FL. Collection of Legislative Acts of the Russian Federation. 2006. No. 52 (1 HR.). Article 5496.

${ }^{3}$ On commercial secrets: Federal Law No. 98-FZ (29.07.2004). Collection of Legislative Acts of the Russian Federation. 2004. No. 32. Article 3283
}

non-cash money. Such objects form an information block, but they differ from the information object (product) because they are of the legally binding (contractual) nature according to Article 128 of the Civil Code of Russia.

2) While analyzing the existing practice of using the category "information object", it is possible to come to a conclusion that it refers to different works created in electronic form or transformed to electronic (digital) form.

3) It is possible to identify a specific feature of such objects, which reflects their ability to satisfy the needs of consumers. These products are useful and valuable, they have a price. Their owner can benefit from using them. This can be proved by some other legal norms. For example, according to the provisions of Articles 57, 58 of Federal Law No. 212-FZ of 24.07.2009 "On Insurance Fees to the Pension Fund of the Russian Federation, Fund of Social Insurance and Fund of Obligatory Medical Insurance", the profit from realization of information products makes the base for calculating insurance fees for organizations and private persons.

Exclusion of information objects from the list of private property objects was made by the legislator for the following reasons. According to the intent of the legislator, in order to protect social interests and ensure rights of all the citizens, objects which are not protected as artistic works (productions) and do not refer to other objects of intellectual rights, should be freely available without any charge. For example, laws of the Russian Federation, legislation of other countries, international legislation existing in electronic form on sites of the corresponding organizations were not categorized as information products. Otherwise, it could cause unreasonable restrictions of rights to information. On the other hand, legal-reference systems "ConsultantPlus", "Garant" and others, which combine the features of databases and computer programs, are information objects themselves.

Information services are also recognized as objects of civil rights, considered to be a special way 
of information products presentation. This causes another collision between the constitution right to free access to information and the special regime of intellectual property objects and the way of their presentation.

Therefore, exclusion of information from the objects of civil rights has not solved all the problems.

Artistic works have an information nature and possess all the features of information, they can be easily copied and reproduced.

The adaptation of the term "reproduction" to the electronic form of intellectual property objects causes a lot of problems. "Reproduction" is a special way of intellectual property use and it becomes the main (basic) way of intellectual property dissemination.

Downloading of artistic works to information carriers (saving in electronic form) is often associated with the risk of copying.

In Russian legislation, the right to reproduction is based on the Berne Convention and is enshrined in Article 1270 of the Civil Code of the Russian Federation. The WIPO treaties on copyright and performances and phonograms provide: "The right to reproduction... and exceptions permitted by this article can be fully applied to the digital sphere, including in respect of the use of works in digital form... storage of a protected work in digital form is its reproduction.." 1 .

Thus, the dependence of "storage" of intellectual property rights objects in relation to the term "reproduction" concerning digital forms of storage and reproduction on electronic media is stated at the international level.

However, this provision is not applicable to some objects of intellectual property rights, for example computer software programs.

Computer programs are special objects of copyright and are considered by the legislator as literary works, although this approach is quite disputable.

\footnotetext{
${ }^{1}$ The WIPO Treaty on performances and phonograms (Signed 20.12.1996). [Electronic resource]. Access from "ConsultantPlus.
}

In legal practice, the computer program "SYSTEM GARANT" was referred to information objects $^{2}$ as well as a single integrated information service GIS in the Ulyanovsk region ${ }^{3}$, and an edition of the television program "News". In the case of Billington, ${ }^{5}$ scanned books were qualified as "digital products".

According to the nature of software as a commodity and a consumer product, for normal operation of a computer it is necessary to save the program in its memory and keep it there during the entire period of using the computer. Therefore, the use of a particular computer program by the owner of the material medium (system unit) may only be exercised on the basis of "storing" this program in the computer's memory. Thus, a specific feature of this kind of intellectual property objects concerning their existence in digital form is the fact that their storage on an electronic carrier itself is reproduction and use at the same time. Therefore, the category "storage" as a separate category characterizing a legal fact cannot be applied to computer programs because the terms "recording" and "reproduction" in relation to computer programs concern not only the time of recording, but also the programs in the computer's memory. In this case, the fact of "recording" (saving) on an electronic carrier or paper is a form of existence of computer programs as an object of right.

Nevertheless, application of the categories "recording", "storage" and "reproduction" causes certain difficulties in the Russian court practice.

Such categories as information field, virtual and cyber space are closely connected with the definition of information. It should be mentioned that no legal definitions of these categories exist

\footnotetext{
2 Act of FAC Moscow district dated 15.04.2013 No. A40107734/12-35-1016. [Electronic resource]. Access from "ConsultantPlus.

${ }^{3}$ Act of FAC Volga district dated 05.03.2013 No. A726640/2012. [Electronic resource]. Access from "ConsultantPlus.

${ }^{4}$ Act of the Arbitration court of the North-West district dated 27.08.2014 No. A26-8643/2013. [Electronic resource]. Access from "ConsultantPlus.

${ }^{5}$ US EX REL. v. Billington, 985 F. Supp. 604 (D. Md. 1997). Available at: http://law.justia.com/cases/federal/district-courts/ FSupp/985/604/1569276/ (accessed 09.12.2016).
} 
in Russia nowadays. Some interpretations of the terms can be found in legal practice. In the Act of the Supreme Court No. APL13-538 (12.12.2013) it is stated that telematic services involve the use of cyber space ${ }^{1}$.

The Act of the Presidium of the Supreme Arbitration Court of the Russian Federation (dated 16.01.2001, case No. 1192/00) contains the following definition of the term "Internet": "a grouping of computers that are connected to each other via telephone or other means of communication. This network makes it possible to exchange information"2.

Many attempts have been made to give a definition of the term "cyberspace".

For example, D. V. Gribanov considers cyberspace to be "public relations arising in connection with the use of a computer network. Information and information resources are objects of such relations" [3, p. 60].

L. Lessing made a comprehensive review and grouping of methods regulating the Internet. $\mathrm{He}$ believed that there are four main types of regulation in this field: by relevant laws; social norms; economic laws; technical standards [16, p. 508].

Some attempts to develop concepts of the regulation of the Internet environment have also been made in Russia. At the end of the last century, B. Cristalny and M. Yakushev suggested a variant of the Russian legislation in the field of the Internet [6, p. 24]. In 2008 a "Concept of legal regulation of public relations arising in the process of using the information environment of the Internet"3 was worked out and the Centre of Internet technologies

${ }^{1}$ Act of the Suprene Court of 12.12.2013 No. APL13-538

"About the upheld decision of the Supreme Court of the Russian Federation dated 24.09.2013 No. AKPI13-695, which rejected the application for recognition partially invalid the paragraph 32 of the Rules of rendering of telematic communication services, approved. Decree of the RF Government dated 10.09.2007 No. 575". [Electronic resource]. Access from "ConsultantPlus.

${ }^{2}$ Act of the Presidium of the SAC dated 16.01.2001 No. 1192/00 No. A40-25314/99-15-271. [Electronic resource]. Access from "ConsultantPlus.

${ }^{3}$ The concept of establishing the legal regulation of public relations arising in the process of using the information environment of the Internet. Available at: http://www.ifap. $\mathrm{EN} / \mathrm{pr} / 2008 / \mathrm{n} 081211 \mathrm{~d}$.pdf (accessed 28.10.2016).
(ROTsIT) presented in the Federation Council a draft law "On the Internet". In 2009 the legislators planned to adopt the bill "On basic principles of legal regulation of activity on the Internet", develop a law "On regulation of the Russian segment of the Internet" ${ }^{5}$ and a number of other documents. However, all this remains to be only plans, and none of the proposed concepts have been implemented at the legislative level.

That is why the question of punishment for the violation of intellectual property rights and illegal use of data and information products in the Internet is still unresolved in Russia.

In our country, there is an approach that is fixed in the Decree of the Supreme Arbitration Court of the Russian Federation of 23.12.2008 No. $109.62 \% 08$, according to which it is necessary to clarify some facts in order to determine the absence or presence of grounds for responsibility of a site owners and hosting providers for hosting content that violates intellectual property rights. In Particular. it is necessary to find out if:

- the website owner and hosting provider initiated transfer of the content;

- the website owner and hosting provider selected a particular person to receive the content;

- the website owner and hosting provider are responsible for the maintenance and integrity of the content $^{6}$.

Later, the Presidium of the Supreme Arbitration Court of the Russian Federation added the list with the necessity to establish the following circumstances:

- if the above named actors profited from posting the content;

\footnotetext{
${ }^{4}$ The draft law "About bases of legal regulation of the Internet". Available at: http://nag.ru/news/newsline/16003/pervyiyvariant-zakonoproekta-ob-osnovah-pravovogo-regulirovaniyadeyatelnosti-v-seti-internet-.html (accessed 28.10.2016).

${ }^{5}$ The draft law "On regulation of the Russian segment of the Internet". Available at: http://www.libertarium.ru/17224 (accessed 28.10.2016).

${ }^{6}$ Act of the Supreme Arbitration Court of the Russian Federation dated 23.12.2008 No. 10962/08. [Electronic resource]. Access from "ConsultantPlus.
} 
- if there are any restrictions concerning the volume of information being posted and its availability for other persons;

- if the responsibility of the user is defined in the user agreement.

- if there are any technological conditions causing violation of the exclusive rights or any programs that make it possible to identify and remove prohibited content ${ }^{1}$.

The proposed procedure reflects the position of the Supreme Arbitration Court of the Russian Federation $^{2}$ and other courts ${ }^{3}$ of the Russian Federation. For example, based on the abovenamed criteria the holders of "Rambler" portal were brought to justice ${ }^{4}$.

In legal practice, several approaches addressing the issue of protection of intellectual property rights in the Internet sphere have been formulated.

The first way to protect intellectual property rights existing in digital form is the use of special technical means. Articles 1299, 1309 of the Civil Code regulate the use of technology in the protection of copyright and related rights. Some of Russian legal experts believe that technical means, for example, a special program that can block the possibility of reproduction (copying) of the object, should act as the main kind of protection of infringed rights. They also believe that technology is the most effective means of protection. This can be explained by the following

The use of technical means is associated with a particular virtual unit or an information carrier, de-

\footnotetext{
${ }^{1}$ Act of the Presidium of the Supreme commercial Court dated 01.11.2011 No. 6672/11. [Electronic resource]. Access from "ConsultantPlus.

${ }^{2}$ Act of the Supreme Arbitration Court of the Russian Federation from September 28, 2012 No. VAS-10781/12 No. A4042674/11-67-370. [Electronic resource]. Access from "ConsultantPlus.

${ }^{3}$ Act of the Federal arbitration court of the Moscow district of 23 April 2012 on business No. A40-42674/11-67-370. [Electronic resource]. Access from "ConsultantPlus.

${ }^{4}$ Act of the Ninth arbitration court of appeal dated 01.02.2010 on the case No. A40-89751/09-51-773. [Electronic resource]. Access from "ConsultantPlus.
}

vice, but not with the user. The use of special blocking software allows for stopping the violation of law and for prosecuting the violator of law. In the virtual space, it is difficult to identify the offender: in most cases it is possible to find only the IP address of the device that was used to violate intellectual property rights. However, even if the offender has been identified, it is very difficult or even impossible to punish him because he can be a subject of jurisdiction of another state. The peculiarity of offenses in cyberspace is that it is easy to remove or delete prohibited content before the fact of violating rights is established.

According to many experts, the use of special technical means and software for blocking a network address of the offending website is not effective and can not be applied to all sites. This problem can be solved by blocking not the network address but the particular URL-link.

The situation with violation of intellectual property rights in Russia is quite complicated. Unlawful manufacture and distribution of counterfeit video and audio products, replication of the most popular computer programs are widespread [4, p. 22].

The Internet space is the most convenient and attractive area to commit crimes against information objects. Its growing potential, high degree of anonymity, and extremely poor control over transactions and transfer of information objects create almost unlimited possibilities for using the Internet as a tool to commit offenses in the field of copyright and intellectual property, commercial use of information objects without permission of the creators, owners, other rights holders [12, p. 35]. All this has caused a great number of copyright violations, damage from which amounts to millions of euros [8, p. 315].

Analyzing the opportunities of protection of information objects in the digital space and on the 
Internet, it is important to take the current Russian legislation and international law.

Copyright on the Internet is regulated, first of all, by a number of major international acts. These include the Berne Convention for the protection of literary and artistic works (9 September 1886), Universal Copyright Convention (6 September 1952) and some others. In fact, regulation of copyrights on the Internet in the international sphere is based on multilateral agreements in the field of intellectual property protection connected with the operations in the Internet. The main problem in this area is the lack of uniform regulation for all participating countries, as these multilateral agreements are declarations (not norms of direct action) $[15$, p. 37]. International treaties only formulate the basic principles of regulation and interaction between countries on specific kinds of relationships in the information sphere - the principles that can be laid in the foundation of the national legislation of the countries.

In the Russian Federation today the legal regulation of the Internet is based on the provisions of national legal acts, the most important of which is the Constitution of the Russian Federation and the Civil Code of the Russian Federation (Part Four), as well as the provisions of Federal Law No. 364-FZ of 24.11.2014 On Amendments to the Federal law "On information, information technologies and protection of information" and the Civil Procedure Code of the Russian Federation"1.

The provisions of Federal Law No. 364-FZ regulate the actions of the Internet sites owners who violate exclusive rights when posting content. In particular, offenders are responsible for ignoring complaints from the copyright holders.

This law provides the possibility of pre-trial settlement of disputes between the owner of the

\footnotetext{
${ }^{1}$ On amendments to the Federal law "On information, information technologies and protection of information" and the Civil procedural code of the Russian Federation: Federal Law dated 24 November 2014 No. 364-FZ. Rossiyskaya Gazeta Russian Gazette. 2014. 27 Nov.
}

offending website and holders of the infringed intellectual property rights concerning blocking (banning) of the offending website.

The provisions of the law also expand the list of intellectual property objects protection of which becomes possible by establishing operational access restriction. This law protects not only video content, but also software, literary and musical works.

The particular question which arose after the adoption of Federal Law No. 364-FZ and is widely discussed in the Internet sphere is the risk that legal provisions can be used against any network resources, including major ones (e. g., Wikipedia).

One of the most serious shortcomings of the law is the possibility to block those Internet resources which do not violate copyright and (or) related rights but have the same IP address as the siteoffender.

Finally, a major problem in the field of protection of intellectual property rights in the digital sphere and the Internet is the fact that the current legislation does not forbid the owners of the blocked Internet resources to create new sites, which can also be used for copyright infringement [8, p. 316].

It is necessary to pay special attention to the application of tough measures against counterfeit products. The rules of free use of intellectual property and various kinds of information ought to be changed. The responsibility for the dissemination, use and reproduction of information ought to be introduced.

Thus, we can come to a conclusion that at present time the existing legal regulation of circulation of information objects is not perfect in Russia. There is no special regulation of specific actions and relationships in the Internet sphere. To eliminate this drawback, it is necessary to implement regulation of both the Internet space in general and the procedure of circulation of particular information objects in it. In particular, transactions 
for purchasing various software products, audiovisual works and other information products are becoming more and more extensive, and require a special legal regime.

Objections against the protection of violated rights by using a special program for blocking a network address of the offender can be explained by the following.

1) The use of this method does not provide the protection for a number of other types of intellectual property rights, including patent rights and rights to selective achievements.

2) Article 12 of the Civil Code expressly names the possibility of self-use of technical means as a method of self-defense, which changes the legal status of this method.

3) The program that can block (ban) an IP address of the offending website may not be applicable to sites-offenders for which the site owner uses a special protected access, implying hiding of the IP address.

4) After the IP addresses blocking is detected, the address can be changed in order to circumvent the installed block. It can be done manually or automatically, by connecting a special program which periodically changes the network address.

5) Using of the program that can block the IP address of the offending website can affect all sites that use the same IP address (not only the offending one). All that can violate the rights of honest owners and users.

6) It is impossible to provide a complete control over the digital space even by using legal and technical means at the same time, because the virtual space is not limited by the territory of a state and thus has no strict boundaries to determine the national jurisdiction.

Thus, scientific literature clearly states that it is impossible to ensure protection of intellectual property rights by using only technical means. Therefore, some experts propose to establish the possibility of non-contractual and free use of all electronic resources [1, p. 78].

Secondly, in Russian legal science there is a position according to which intellectual property rights in the Internet space ought to be regulated by international (not national) law. According to this approach, it is proposed to establish a special list of intellectual property at the international level, which would contain information about all objects of copyright. Some electronic publishers work with special systems such as Print-on-Demand Publishing, BookSurf Suite. These programs give the copyright holder the possibility to control the transfer of fees for reproduction of their works on the Internet. Unfortunately, not all objeets can be controlled in such a way. The implementation of control systems ought to be improved.

Moreover, even this position raises many objections, because it is very difficult to reach an agreement in the virtual space regulation at the international level. This can be explained by differences in the historical development. The unification and harmonization of relations in the information space are not possible because of the high degree of differences between the members of the international community and wide use of the Internet resources and information space to serve political purposes. In different countries, there are different models (monistic and dualistic) of the legal copyright regulation and various national systems of registration of patent rights. Almost every state has its own peculiarities of regulation of intellectual property, which can be explained by the historical development. The lists of intellectual property objects under protection are different in many countries. Finally, the dynamic development of information and computer technologies also complicates the process of legal regulation of this sphere, because it requires constant changes of the legislation caused by the change of intellectual property objects and modification of ways of copyright violation.

According to many researchers of law, the problem of infringement of intellectual property rights on the Internet is difficult to resolve by only technical or only legal means. In the information sphere, there is a constant competition among website owners, as well as a constant struggle between right holders and offenders for free access to information. And the more perfect 
become protection programs, the more kinds of violation appear.

In this regard, it is possible to suggest the following model of dealing with electronic objects in the virtual sphere in Russia: the copyright holder receives compensation from providers for placement of the intellectual property object on the Internet (by agreement of the parties), but not from the Internet users; in order to avoid indirect imposing of the provider's costs upon the Internet users, the authorized body sets a limit on the cost of the Internet connection; a provider will be brought to justice in case of violation of the rights to the information product, but he has the right of regress to the person who unlawfully uploaded the infringing content.

The main preventive measures for intellectual property protection in virtual sphere are: deposit, watermarks, use of the copyright symbol (C).

In order to make a deposit, the copyright holder can submit a special application and receive a certificate of acceptance of the intellectual property object. A laser disc is used to save information from the site in the web-depository. This method is most relevant to copyright and related rights which are not registered in Russia in any special way. In this regard, V. B. Naumov 20 years ago suggested creating a web-depository-databank which could contain control copies of electronic documents and sites [9, p. 98] Some authors propose to make deposits with the help of notaries $[10, p .13]$.

These methods could be improved by the creation and functioning of a special council consisting of representatives of the state bodies, the main purpose of which would be to provide the necessary legal, informational and economic space for functioning of intellectual property law [5, p. 31].

The category "storage" cannot be applied to computer software programs because the terms "recording" and "reproduction" in relation to computer programs concern not only the time of recording but also the further presence of programs in the computer memory, since putting into written or dig- ital form is a form of existence of computer programs as objects of right.

The fact of the program being stored in the computer memory will testify to its being used by the owner of the material media until proven otherwise. Thus, what is specific about the existence of intellectual property objects in digital form is that their storage on an information carrier itself proves reproduction and use. It is possible to recommend the legislator to duplicate the provisions of the WIPO treaties in Part Four of the Civil Code of Russia.

Article 1299 of the Civil Cade contains provisions which prohibit "manufacturing, distribution, rental, provision for temporary free use, import, advertising of any technology, any technical device or their components, use of such technical means for the purpose of obtaining profit or rendering corresponding services, if it causes problems for the use of technical means of copyright protection, or these technical means cannot ensure proper protection of copyright".

The joint Resolution of the Plenum of the Supreme Court and the Higher Arbitration Court of 26.03.2009 notes that "this prohibition does not cover cases when technology, technical devices or their components were originally developed, manufactured and distributed not for the purposes related to circumvention of technical means of protection"1. Thus, the current legal regulation also does not establish responsibility for the production of programs that were created and used only for finding "weak" points in the software.

The USA is the leader in creating and selling information products. Therefore, laws of the United States in the field of protection of information are of a special interest for us.

The US legislation lacks any legal definition of "information". It only contains the basic principles

\footnotetext{
${ }^{1}$ The resolution of the Plenum of the RF Supreme Court No. 5 of the Plenum of the Russian Federation No. 29 of 26.03.2009 "On some issues arising in connection with the introduction into effect of part four of the Civil code of the Russian Federation". [Electronic resource]. Access from "ConsultantPlus.
} 
of legal regulation, while norm-definitions are used infrequently. For example, the "Freedom of Information Act" (1966) regulates any relations concerning information which does not refer to the state secrets ${ }^{1}$.

There is no well-defined system of objects of civil rights, including exclusive rights to intellectual property and information, that would be enshrined in legislation. The system of law in the United States largely reflects the British approach: the objects of right include things and intangible objects. The development of intellectual property rights began in the United States in the $18^{\text {th }}$ century, when some States adopted laws on copyright. The adoption of the Constitution in 1787 also influenced the development of intellectual property rights: Congress was appointed to set a period of copyright protection. The law "On Copyright" was adopted in 1790 at the federal level.

Protection of rights to information products in the United States is provided by a system of special institutions.

Firstly, information products are protected by the state bodies, such as CCIPS (Computer crime and intellectual property service) under the U.S. Department of Justice, and USTR.

Secondly, in the USA there are many organizations specializing in protecting the rights of copyright holders in cyberspace.

Thirdly, there is a system of state institutions that provide the right to free access to information: Office of General Counsel (NDLP), Library of Congress.

The copyright law of the US provides the right to make copies of works for various non-profit archives and libraries to preserve the scientific and literary heritage.

An important step in the development of US legislation in the field of intellectual property was formation of the information economy, expansion of cooperation in cyberspace, development of the Internet. The main legal provisions concerning the

${ }^{1}$ The freedom of information act 5 U.S.C. $\S 552.104-231.110$ STAT. 3048. Available at: https://www.justice.gov/oip/blog/ foia-update-freedom-information-act-5-usc-sect-552-amendedpublic-law-no-104-231-110-stat (accessed 07.11.2016) regulation of intellectual property relations in the digital space were developed in the USA in 1998. These provisions covered regulation of the information field, virtual and cyber space, as well as information itself. However, legal definitions of these categories do not exist in the United States nowadays. Interpretation of these terms can mainly be found in legal practice. For example, the U. S. Supreme Court interprets the Internet as a "network of networks", "a new method of access to information", "network of interconnected computers", and considers cyberspace as a "unique environment that is not located in geographical space, but is available to everyone anywhere in the world, through access to the Internet"3.

Unlicensed use of intellectual property rights on the Internet in the USA is called "transformativeness". Protection is only granted to the original work, not to its copies placed in the Internet space. Also, in the ease Feist Publications vs. Rural Telephone Service, it was determined that a copyright violation may not be recognized in relation to compilations or works which differ from the original ${ }^{4}$.

The widest development of the information environment, huge growth in the volume of exports of information products and services objectively required improvement of legislation in this sphere. As a result, in 2009 the USA developed the program "On protection of intellectual property rights through improved information policy", aiming to create a mechanism to ensure a balance between the rights of authors and the rights of citizens to receive information.

Two years later - in 2011 - "Protect Intellectual Property Act (PIPA)" and "Stop Online Piracy Act (SOPA)" were introduced to the Senate.

"Protect Intellectual Property Act (PIPA)" provides measures aimed at the protection of rights

\footnotetext{
${ }^{2}$ National cable \& Telecommunications ASSN v. Brand X internet services (04-277) 545 U.S. 967 (2005). Available at: https://www.law.cornell.edu/supct/html/04-277.ZS.html. (accessed 10.10.2016).

${ }^{3}$ Reno vs. ACLU, 117 S. Ct. 2329 (1997) (casebook at 932-53). Available at: http://www.ciec.org/SC_appeal/opinion. shtml. (accessed 15.09.2016).

${ }^{4}$ Feist Publications v. Rural Telephone Service 499 U.S. 340 (1991). Available at: https://supreme.justia.com/cases/federal/ us/499/340/ (accessed 07.11.2016).
} 
holders whose rights have been violated by posting illegally obtained information on the Internet sites. This bill gives a definition of the Internet site specially created to commit offenses. This "Internet site is aimed at the reproduction, distribution or public performance of works protected by copyright (that violate intellectual property rights), or to alienation, distribution, or advertising of goods, services, trademarks, signs and symbols which are used illegally; an Internet site that gives reasons to believe that the site is used for illegal purposes"1.

According to the second of these bills - "Stop Online Piracy Act" (SOPA), ${ }^{2}$ a search website, a website that is hosting copyrighted material, a service provider, payment services, services of Internet advertising can be hold responsible for copyright infringement. In the case the copyright holder receives a notification about the violation of his rights, the stated subject must stop the interaction with the website-infringer, remove the content in question and links to the site-infringer, cease to provide its technical support, suspend payment transactions, etc. If the Prosecutor General issues a corresponding order, the service provider is obliged within 5 days to block the access of consumers in the United States to sites whose content violates intellectual property rights, including any access to the $1 \mathrm{P}$ address of this site; Internet advertising services must stop advertising the offending website.

It should be noted that these bills gave rise to numerous and active discussions in the United States. In January 2012, the major search websites (Google, Facebook, Zynga) organized a broad protest action against these bills: these Internet companies changed the color of the sites, painting them black, and sent a petition to the Senate to prevent the bills from being adopted [21].

\footnotetext{
${ }^{1}$ Protect Intellectual Property Act (PIPA). Available at: https://www.govtrack.us/congress/bills/112/s968/text (accessed 18.10.2016).

${ }^{2}$ Stop Online Piracy Act. Available at: https://www.congress. gov/bill/112th-congress/house-bill/3261 (accessed 18.10.2016).
}

The work on those bills was stopped because of the serious objections to a number of their provisions. The bills aimed to provide sufficient protection of the rights of copyright holders. The intention was to impose strict measures (including criminal liability) for violation of intellectual property rights in order to secure the rights of owners and holders of intellectual property. Opponents of the adoption of the PIPA and SOPA argued that the application of restrictions, prohibitions, strict procedures for the protection of intellectual property rights, especially to information, is disproportionate, violates the balance of interests of right holders and users. In addition, there is a broad list of circumstances entailing the obligation of providers, users and other persons to stop using the content when viølation of copyright is only being expected, which gives the opportunity to misuse the rights, and is regarded as the evidence of unreasonable restriction of the freedom of speech. All this can cause serious problems with the use of the Internet space.

The practice of protection of intellectual property rights is the most developed in the United States. In the country's judicial practice, one can find precedents for all kinds of protection in the field of intellectual property.

\section{Conclusions}

Today due to the shortcomings of the Russian legislation, there are a lot of approaches among scholars to understanding the nature of information, its place among other objects of property rights, as well as to its correlation with documented information as that recorded on material carriers. The most difficult is the question of the application of property rights and exclusive intellectual property rights to informational resources and their components. The question of regulation of relations on the transfer of information under the contract is also very complicated [7].

The analysis of the existing definitions of the term "information" has revealed that different information theories did not contribute to working out 
a generally accepted definition. The nature (essence) of information makes it possible to refer information (as a category of civil law) to intangible property, which has a special regime. The Law on information regards information as data, which characterizes its ideal features, but does not regulate the process of its fixation and transfer.

The research results prove that information can be not only an independent object of the civil legal regulation but can also be regarded as a special form of existence of civil relations. All this makes it possible to divide information objects into three components: ideal information, forms and means of its organizing and structuring, and a material carrier of information [2, p. 57].

Each of these components is traditionally regulated by different law institutes. A material carrier of information (as a thing) is regulated by property rights or contractual rights according to Article 3 of the Law on information. The ideal content of information is regulated by Part Four of the Civil Code of the Russian Federation (as intellectual property). Limitations on information circulation are established by special laws on state secrets, commercial secrets and laws concerning other kinds of secret information. Information in open access, as a component of legal relations between the subjects of civil circulation (e.g. information obtained through marketing research which is not of a confidential nature), is not regulated properly.

All the above stated makes it possible to come to the following conclusions.

Information is a special independent ideal object of private and public law.

The notion of information is wider than the notion of intellectual property as it also includes unprotected information.

Legal protection of information ought to take into account the specific features of every kind of information and its status.

Recognition of information as an independent object of law can be explained by its value and by the necessity to protect information as an ideal free circulating intangible object.

Exclusion of information objects from the objects of civil law has caused numerous collisions in this sphere.

In order to solve the problems, it is necessary to introduce a differentiated legal regulation of information and of any actions aimed at creation, storage, copying, dissemination and use of information.

Special attention ought to be paid to the questions of protection and civil circulation of such information. Some authors suggest including information in the list of intangible things (Article 150 of the Civil Code of Russia), others suggest including it in the list of civil law objects. To improve legal regulation, it is possible to give the following definition of an information object: it is an object of intellectual property which exists in electronic form as a set of symbols and signals and has a real or potential commercial value.

References
1. Budnik R. Etalonnyy tsifrovoy fayl vmesto kopirayta [Reference Digital File instead of Copyright]. Khozyaystvo i pravo - Business and Law. 2009. Issue 7. Pp. 77-81. (In Russ.).

2. Voynikanis E. A., Yakushev M. V. Informatsiya. Sobstvennost'. Internet: Traditsiya i novelly $v$ sovremennom prave [Information. Property. Internet: Tradition and Novels in Modern Law]. Moscow, 2004. 300 p. (In Russ.).

3. Gribanov D. V. K voprosu o pravovoy teorii kiberneticheskogo prostranstva [On the Issue of Legal Theory of Cyber Environment]. Gosudarstvo i pravo - State and Law. 2010. Issue 4. Pp. 57-62. (In Russ.).

4. Danilina I. V. Informatsionnye otnosheniya $v$ seti Internet po povodu ob"ektov avtorskikh prav [Informational Relations on the Internet Concerning Copyright Objects]. Zakony Rossii: opyt, analiz, praktika - Laws of Russia: Experience, Analysis, Practice. 2010. Issue 4. Pp. 20-25. (In Russ.).

5. Esen'kin B.S. Problemy standartizatsii $i$ zashchity intellektual'noy sobstvennosti [Problems of Standardization and Protection of Intellectual Property]. Nauchnaya periodika: problemy $i$ 
resheniya - Scholarly Communication Review. 2011. Issue 2. Pp. 29-32. (In Russ.).

6. Kristal'nyy B., Yakushev M. Kontseptsiya rossiyskogo zakonodatel'stva $v$ oblasti Interneta [Concept of the Russian Legislation in the Field of the Internet]. Informatsionnye resursy Rossii - Information Resources of Russia. 2000. Issue 2. Pp. 19-26. (In Russ.).

7. Metodologicheskie problemy tsivilisticheskikh issledovaniy: sbornik nauchnykh statey; otv. red. A. V. Gabov, V. G. Golubtsov, O. A. Kuznetsova [Methodological Problems of Civil Law Studies: Collected Articles; ed. by A. V. Gabov, V. G. Golubtsov, O. A. Kuznetsova]. Moscow, 2016. 192 p. (In Russ.).

8. Mirskikh I. Yu., Mingaleva Zh. A. Vliyanie deystvuyushchego zakonodatel'stva na razvitie intellektual'noy deyatel'nosti $v$ Rossiyskoy Federatsii [Influence of Changing the Current Legislation upon the Development of Intellectual Activity in the Russian Federation]. Vestnik Permskogo universiteta. Yuridicheskie naukiPerm University Herald. Juridical Sciences. 2016. Issue 3(33). Pp. 311-318. (In Russ.). DOI: $\quad 10.17072 / 1995-4190-2016-33-311-318$. WOS: 000393284500008.

9. Naumov V. B. Pravovye problemy sushchestrovaniya informatsii $v$ seti Internet [Legal Problems of the Existence of Information on the Internet]. II Sankt-Peterburgskaya Assambleya molodykh uchenykh i spetsialistov, 8 dekabrya 1997 g. - The $2^{\text {nd }}$ St. Petersburg Scientific Conference of Young Scientists and Specialists (December 8, 1997). St. Petersburg, 1997. Pp. 95-96. (In Russ.).

10. Neznamov A.V. Deponirovanie ekzemplyarov avtorskikh proizvedeniy kak element podvedomstvennosti yunidicheskikh del organam notaria$\mathrm{ta}$ TThe Deposition of Copies of Author's Work as an Element of Notarial Jurisdiction]. Arbitrazhnyy $i$ grazhdanskiy protsess - Arbitrazh and Civil Procedure. 2010. Issue 12. Pp. 11-14. (In Russ.).

11. Ozhegov S. I., Shvedova N. Yu. Tolkovyy slovar' russkogo yazyka [Explanatory Dictionary of the Russian Language]. 2002. 250 p. (In Russ.).

12. Razuvaev V., Averina O. Nuzhen li zakon ob Internete? [Is the Law on the Internet Necessary?]. EZh-Yurist - EZh-Jurist. 2010. Issue 39. Pp. 34-36. (In Russ.).

13. Simonovich $S$. V. Informatika dlya yuristov $i$ ekonomistov [Informatics for Lawyers and Economists]. 2004. 640 p. (In Russ.).
14. Shannon K. E. Raboty po teorii informatsii $i$ kibernetike [Works on the Information Theory and Cybernetics]. 1963. 832 p. (In Russ.).

15. Becker J. Territoriality, Copyright Protection on the Internet and Liability Questions. Int. Assoc. Sci. Techn. \& Med. Publishers. 1998. Pp. 32-39. (In Eng.).

16. Lessing L. The Law of the Horse: What Cyberlaw Might Teach. Harvard Law Review. 1999. No. 113. Pp. 507-508. (In Eng.).

17. Logan $R$. $K$. What is Information? - Propagating Organization in the Biosphere, the Symbolosphere, the Technosphere and the Econosphere. Toronto: DEMO Publishing, 2014. (In Eng.).

18. MacKay D. J. C. Information Theory, Inference, and Learning Algorithms. Cambridge: Cambridge University Press, 2003. 640 p. (In Eng.).

19. McEliece $R$. The Theory of Information and Coding. Cambridge, 2002.397 p. (In Eng.).

20. Mingaleva Zh., Mirskikh I. The Problems of Legal Regulation and Protection of Intellectual Property. Procedia Social and Behavioral Sciences. 2013. No. 81. Pp. 329-333. (In Eng.). DOI: $10.1016 /$ j.sbspro.2013.06.437.

21. Mingaleva Zh., Mirskikh I. Psychological Aspects of Intellectual Property Protection. Procedia-Social and Behavioral Sciences. 2015. No. 190(2015). Pp. 220-226. (In Eng.). DOI: 10.1016/j.sbspro.2015.04.938.

22. O'Leary D. E. Computer-Based Political Action: The Battle and Internet Blackout over PIPA. Available at: https://msbfile03.usc.edu/digitalmeasures/oleary/intellcont/Pipa-Social-Media-1. pdf. (accessed 18.10.2016). (In Eng.).

23. Stone J. V. Information Theory: A Tutorial Introduction. University of Sheffield, England, 2014. 42 p. (In Eng.).

\section{References in Russian}

1. Будник Р. Эталонный цифровой файл вместо копирайта // Хозяйство и право. 2009. № 7. C. $77-81$.

2. Войниканис Е.А., Якушев М. В. Информация. Собственность. Интернет: Традиция и новеллы в современном праве. М.: Волтерс Клувер, 2004. 300 с.

3. Грибанов Д. В. К вопросу о правовой теории кибернетического пространства // Государство и право. 2010. № 4. С. 57-62

4. Данилина И. В. Информационные отношения в сети Интернет по поводу объектов авторских прав // Законы России: опыт, анализ, практика. 2010. № 4. С. 20-25. 
5. Есенькин Б. С. Проблемы стандартизации и защиты интеллектуальной собственности // Научная периодика: проблемы и решения. 2011. № 2. C. 29-32.

6. Кристальный Б., Якушев М. Концепция российского законодательства в области Интернета // Информационные ресурсы России. 2000. № 2. С. 19-26.

7. Методологические проблемы цивилистических исследований: сб. науч. ст. / отв. ред. А. В. Габов, В. Г. Голубцов, О. А. Кузнецова. М.: Статут, 2016. 192 с.

8. Мирских И. Ю., Мингалева Ж. А. Влияние действующего законодательства на развитие интеллектуальной деятельности в Российской Федерации // Вестник Пермского университета. Юридические науки. 2016. Вып. 33. С. 311-318. DOI: 10.17072/19954190-2016-33-311-318.

9. Наумов В. Б. Правовые проблемы существования информации в сети Интернет // II Санкт-Петербургская Ассамблея молодых ученых и специалистов, 8 декабря 1997 г.: сб. докл. и тез. СПб., 1997.

10. Незнамов А. В. Депонирование экземпляров авторских произведений как элемент подведомственности юридических дел органам нотариата // Арбитражный и гражданский процесс. 2010. № 12. С. 11-14.

11. Ожегов С.И. Шведова Н.Ю. Толковый словарь русского языка. М., 2002. 250 с.

12. Разуваев В., Аверина О. Нужен ли закон об Интернете? // ЭЖ-Юрист. 2010. № 39. C. 34-36.

13. Симонович C. В. Информатика для юрисстов и экономистов. СПб.: Питер, 2004. 640 с.

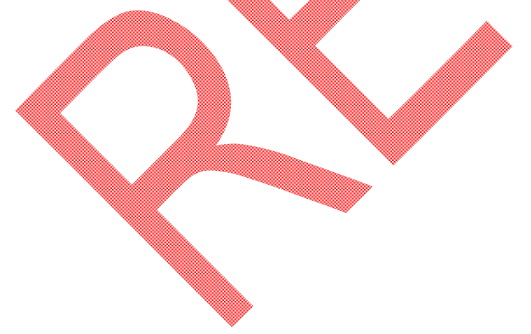

14. Шеннон К. Э. Работы по теории информации и кибернетике. М.: Изд-во иностр. лит., $1963.832 \mathrm{c}$.

15. Becker J. Territoriality, copyright protection on the Internet and liability questions // Int Assoc Sci Techn \& Med Publishers. 1998. Pp. 32-39.

16. Lessing $L$. The Law of the Horse: What Cyberlaw Might Teach // Harvard Law Review. 1999. № 113. Pp. 507-508.

17. Logan R. K. What is Information? - Propagating Organization in the Biosphere, the Symbolosphere, the Technosphere and the Econosphere, Toronto: DEMO Publishing, 2014, $195 \mathrm{p}$.

18. MacKay D. J. C. Information Theory, Inference, and Learning Algorithms. Cambridge: Cambridge University Press, 2003. 640 p.

19. McEliece $R$. The Theory of Information and Coding. Cambridge, 2002. 397 p.

20. Mingaleva Zh., Mirskikh I. The Problems of Legal Regulation and Protection of Intellectual Property $\%$ Procedia Social and Behavioral Sciences. 2013. № 81. Pp. 329-333. DOI: 10.10 16/j.sbspro.2013.06.437.

21. Mingaleva Zh., Mirskikh I. Psychological Aspects of Intellectual Property Protection // Procedia-Social and Behavioral Sciences. 2015. №190(2015). Pp. 220-226. DOI: 10.1016/j. sbspro.2015.04.938.

22. Oteary D. E. Computer-Based Political Action: The Battle and Internet Blackout over PIPA. URL: https://msbfile03.usc.edu/digitalmeasures/oleary/intellcont/Pipa-Social-Media1.pdf. (дата обращения: 18.10.2016).

24. Stone $J . ~ V$. Information Theory: A Tutorial Introduction. London: University of Sheffield, England, 2014. 42 p. 